\title{
POSSIBILITIES OF NEUROSCIENCE APPLICATION IN HOUSING DEVELOPMENT
}

\author{
Andrej NAUMCIK \\ Department of Construction Management and Real Estate, Faculty of Civil Engineering, \\ Vilnius Gediminas Technical University, Saulètekio al. 11, 10223 Vilnius, Lithuania
}

Received 30 April 2020; accepted 15 July 2020

\begin{abstract}
The identification of the best housing alternatives is influenced by a wide variety of factors, including supply, demand, social, cultural, psychological, personal factors. All of these factors have an effect on the behavior and emotional state of a home buyer. What are the most effective ways to choose a home when there is a plethora of complex choices? To determine the most effective choice, neuroscience techniques can be used. These techniques are classified in the following main groups in the article: 1) momentary techniques for measuring changes in electronic neuronal activity, 2) techniques for measuring changes in metabolic neuronal activity, 3) techniques for measuring changes in psychological response to a stimulus. Article's analysis, its identification of advantages and disadvantages of the techniques, representing these groups: electroencephalography, functional magnetic resonance imaging, functional semi-infrared spectroscopy, eye capture, and galvanic skin reactions, has revealed the potential of using latter techniques in making marketing decisions, while working with target audiences of different ages, life experiences, character traits who want to live where they feel best.
\end{abstract}

Keywords: developed environment, housing, buildings, neuroscience, electroencephalography, eye capture.

\section{Introduction}

In the field of housing development, preparing a project for the object and implementing it is no longer enough. Just as in other business sectors, in addition to already existing technological challenges, there are problems, which are now solved by using solutions from relatively distant areas of science. One of these areas with a significant impact on housing development, is marketing, which, in the face of increasing interdisciplinarity, is gaining undeniable importance and weight, in order to meet consumer needs even in highly technology intensive markets. Schaufelberger (2000) identified marketing as one of the most important functions of organizations working in the field of housing development. The need to develop marketing strategies (Dale et al., 2012; Wang \& Liu, 2013; Zeng et al., 2015; Liang \& Gao, 2018) in the field of housing development has become increasingly important in the last few decades.

Market research also plays an important role in housing development (Cariaga \& El-Diraby, 2013; Zhou et al., 2015). For housing developers, it is a necessary part of their development strategies. Over the last few decades, decisions in the field of housing development have been based on personal surveys, experiments, focus group research, aimed at identifying the needs and attitudes of the target audience (Stanton et al., 2017; McDowell \& Dick, 2013; Brenninkmeijer et al., 2020). The effectiveness of these traditional market techniques is becoming increasingly questionable, as in many cases people do not understand and cannot explain their behavior. This phenomenon is caused by the unconscious performance of most activities. According to Agarwal and Dutta (2015), more than 90 percent of mental activity is performed unconsciously and traditional research methods are not suitable for its evaluation. The growing use of neurotechnologies and neuroimaging techniques have influenced the field of market research significantly, particularly in the last decade. In addition to traditional market research methods based on verbal response, there has been an increasing application and development of neuroscience techniques, which allow for an objective assessment of what processes take place in the human brain.

For a long time, the home buyer was seen as a rational decision-maker whose behavior can be explained by traditional market research. This approach was quite conveni-

*Corresponding author. E-mail: andrej.naumcik@capital.lt 
ent: rational behavior could be assessed and measured. As consumer behavior becomes increasingly difficult to explain, it is now recognized, that behavior is not based solely on consciousness and rationality. In addition, consumers themselves often do not know and cannot explain why they have made one decision or another. Under these conditions, traditional market research no longer meets the needs of the modern housing market. As emotions play an increasingly important role in the decision-making process (Ruževičiūtè, 2012), the application of neuroscience methods becomes expedient.

Neuromarketing is a new interdisciplinary field of research, transcending the boundaries of neuroscience, neuroeconomics, and marketing research (Ulman et al., 2015). By combining the views and efforts of representatives of individual schools of scientific thought, an innovative approach to the consumer is formed, and marketing strategies based on the movement of nerve impulses and emotions are developed. Neuromarketing opens up vast new sources of data, opportunities to expand theoretical assumptions, and to visualize cognitive decisionmaking processes (Shealy \& Hu, 2018). Relatively recent neuromarketing techniques presuppose a fundamentally different way to quantify human behavior during the decision-making process. The use of techniques such as electroencephalography, functional magnetic resonance imaging, and eye capture enables the collection of data on neurological responses in the human brain.

Neuroscience techniques in making marketing decisions are applied in a variety of sectors: telecommunications (Adhami, 2013), nutrition (Tichy et al., 2012; Cosic, 2016), cosmetics (Costa et al., 2015), and other sectors. Neuro techniques have been applied to engineering decision making (Hu et al., 2018; Shealy \& Hu, 2018; Hu \& Shealy, 2019). Neuroscience and its techniques are also likely to have huge untapped potential in the field of housing development, so this article aims to uncover the potential of neuroscience in this sector. To this end, the concept and development of neuromarketing is first revealed, followed by a description of neuroscience techniques and the identification of their applications.

\section{Development and concept of neuromarketing}

Neuroscience is a discipline, aimed at analyzing human thoughts, emotions, and behavior, and is a relatively new concept of classical cognitive science, which began to take shape in the middle of the 20th century. Neuroscience itself, as a means of explaining consumer behavior, was introduced in business practice much later, only about a few decades ago, when terms such as neuroeconomics and neuromarketing appeared (Ruževičiūté, 2012). These terms have come to be used as synonyms, but the aims and nature of the concepts of neuroeconomics and neuromarketing differ. Neuromarketing is a sub-discipline of neuroeconomics (Hubert \& Kenning, 2008).

The term 'neuromarketing' was proposed by Smidts in 2002 (Levallois et al., 2019). Since then, the focus of researchers and international organizations on neuromarketing has increased. As noted by Ulman and colleagues (2015), the number of publications examining neuromarketing as an object of research during the period between 2000-2010 increased from 10 to 250 over the period, and more than 300 market research companies were working in the field of neuromarketing research in 2015 (Ulman et al., 2015).

Ulman et al. (2015) proposes to classify the neuromarketing studies conducted so far by directions. The authors identified two directions: consumer neuroscience and the direct application of neuroimaging techniques to achieve sector-specific goals. Both directions of research are interrelated. These trends have also led to a rather wide variety of definitions of neuromarketing (Table 1).

In summary, the content of the neuromarketing concept has expanded over the last few decades. While at the beginning of the twentieth century neuromarketing was treated as an application of neuroscience methods, recent viewpoint on it has been much broader: neuromarketing is already considered an interdisciplinary field of science. Neuroscience methods can also be applied to housing development.

Table 1. Definitions of neuromarketing

\begin{tabular}{|l|l|}
\hline \multicolumn{1}{|c|}{ Authors } & \multicolumn{1}{c|}{ Definition } \\
\hline Lee et al. (2007) & Application of neuroscience methods to analyze and understand human behavior in the market \\
\hline Eser et al. (2011) & Application of neural imaging techniques to understand human behavior in markets and market exchanges \\
\hline Tichy et al. (2012) & $\begin{array}{l}\text { A marketing discipline, which explores the sensory, cognitive, and emotional responses of consumers to } \\
\text { marketing actions }\end{array}$ \\
\hline $\begin{array}{l}\text { Grigaliūnaite and } \\
\text { Pilelienè (2016) }\end{array}$ & Application of neuroscience practice in marketing activities \\
\hline $\begin{array}{l}\text { Oliveira and } \\
\text { Giraldi (2017) }\end{array}$ & $\begin{array}{l}\text { An interdisciplinary field of science using a variety of tools traditionally used in medicine, psychiatry, } \\
\text { psychology to assess measures of neural response, bio-response, and metabolic processes. Neuromarketing } \\
\text { tools are used in conjunction with traditional marketing tools to better understand a variety of emotions, } \\
\text { perceptions, psychological reactions, behaviors, and thoughts }\end{array}$ \\
\hline $\begin{array}{l}\text { Stanton et al. } \\
\text { (2017) }\end{array}$ & $\begin{array}{l}\text { Use of neuroscience and psychology research techniques to gain new insights into consumer behavior, } \\
\text { priorities, decision making, as well as other areas of human cognition and behavior related to marketing }\end{array}$ \\
\hline
\end{tabular}




\subsection{Neuroscience techniques applicable to housing development}

Neuroscience techniques provide the preconditions for identifying what is being focused at and evaluate sensory experiences. These techniques assess memory and the learning process. Probably the most important things neuroscience techniques determine are emotions and motivation (Cosic, 2016). For this purpose, neuroscience techniques fall into the following three groups:

1. Momentary techniques for measuring changes in electronic neuronal activity;

2. Techniques for measuring changes in metabolic neuronal activity;

3. Techniques for measuring changes in psychological response to a stimulus.

The scientific potential of neuroscience technicians is quite high, but attempts to apply them in the field of housing development are quite minimal. Therefore, some neuroscience techniques are discussed in detail, which have not necessarily been applied in the field of housing development, but can potentially be applied in decisions related to the sale of housing.

Electroencephalography (EEG) is a technique where electrodes are placed on the outside of the skull. In this way, the electrical activity of neurons is measured. Jebelli et al. (2017) describe electroencephalography as a noninvasive method of medical imaging to collect data on electrical activity in the brain. Electroencephalography was first tested in 1875 by R. Caton in an experiment on monkeys and rabbits. The first experiments on humans were performed in 1924 (Harris et al., 2018). According to Costa et al. (2015), electroencephalography is a noninvasive procedure, which can be applied to both adults and children. The application of this technique creates preconditions for measuring brain activity.

There are two main sources for electroencephalographic measurements. The first is an electrocorrigram, which is measured directly in the cortex (on the surface of the scalp in a non-invasive manner). The second source is an electrogram used for electroencephalographic measurements by inserting a depth probe directly into brain tissue. Electrograms are only applicable in clinical trials (Jebelli et al., 2017). For this reason, it can be argued, that only electrocorrigrams are suitable as data sources in the housing development sector. Electrograms, as a data source, track voltage fluctuations caused by the activity of neurons on the surface of the brain. In order to collect data on voltage fluctuations, it is advisable to use several electrodes. It should be noted, electroencephalographic data are highly dependent on the location of the electrodes. For example, the cerebral cortex field has the greatest effect on electrical activity. Each part of the cerebral cortex field (anterior lobe, locomotor lobe, parietal lobe, etc.) controls different functions. For example, the anterior lobe is responsible for emotions and the ability to concentrate. The locomotor lobe is important in controlling voluntary movements (Jebelli et al., 2017).
Electroencephalography is usually characterized by rhythmic activity. Rhythmic activities are generally classified into five main wave groups, depending on differences in frequency ranges:

- delta $(0.5-4 \mathrm{~Hz})$;

- theta $(4-8 \mathrm{~Hz})$;

- alpha $(8-13 \mathrm{~Hz})$;

- beta $(13-30 \mathrm{~Hz})$;

- gamma (<30 Hz) (Jebelli et al., 2017).

Delta and theta frequency ranges are most common in infants, children, and sleeping adults. Alpha frequency ranges are associated with conscious thinking, unconscious thoughts, promoting deep relaxation. The beta frequency range is a normal gait rhythm associated with active thinking and concentration. The beta frequency range can clearly show brain activity in the brain motion section. The gamma frequency range has a very low amplitude, so the gamma frequency range is quite rarely found in adults. The gamma frequency range is common in clinical cases where certain brain disorders occur (Jebelli et al., 2017).

Electroencephalogram is one of the most widely used biometric research tools, as it provides a prerequisite for collecting data on both emotional valence and excitation (Ergan et al., 2019). The electroencephalography method has been successfully applied in the study of various aspects of a person's psychology, such as stress, emotional exhaustion, burnout, and mental fatigue. For a long time, electroencephalography was applied only in a laboratory environment using a clinical electroencephalography recording device (such as an electrode cap) and not in real workplaces. The use of this method in real housing construction sites has long been limited by the fact, that the electroencephalography recording device is connected by wires, limiting the uninterrupted work of construction workers. The emergence of modern electroencephalography devices allowing physical movement, has made it possible to apply the method without physical disturbances or wires, quite simply, and without incurring significant financial costs (Jebelli et al., 2017).

Electroencephalographic signals are classified into two main groups: external and internal. External sounds are emitted by the environment (ambient noise, body movement sounds) or by the electroencephalography device itself (electrode movements, wiring system sounds). Internal sounds are heard due to the psychological activities of the body. Electroencephalographic signals are very sensitive to noise of various forms and sources. The quality of electroencephalographic signals is quite low in noisy environments such as construction sites. To eliminate this problem, Jebelli et al. (2018) proposed and validated a signal processing model, enabling the elimination of the sounds of the most common tools and equipment at construction sites.

The popularity of electroencephalography is due to its low application cost and the ability to apply the technique to small samples, which is quite practical (Cosic, 2016). This technique can be applied in a natural and comfort- 
able environment (Hu et al., 2018). Electroencephalography is characterized by excellent temporary resolution because this method is not based on blood flow. Electroencephalography captures the electrical activity of neurons caused by ions and neurons. Another important advantage of electroencephalography is this method's ability to accurately monitor neuronal activity and brain wave structure by directly reaching the central nervous system (Jebelli et al., 2017). The main disadvantage of electroencephalography is poor spatial resolution, as it is difficult to detect specific neuronal sites. Moreover, the method does not make it possible to distinguish cognitive activation from other parts of the brain involved in the mental process (Hu \& Shealy, 2019). It should also be noted, that the application of electroencephalography requires some preparation of the scalp skin (hair removal and coating with a conductive gel), which may be completely impractical in housing construction sites (Jebelli et al., 2017).

Electroencephalography technique has been used to determine the level of stress in construction workers (Jebelli et al., 2018) and to assess work safety (Awolusi et al., 2019). The samples of electroencephalographic examinations are quite small, usually from 5 to 8 study participants (Table 2). This method uses an Emotiv EPOC +, electroencephalography device, or other equipment is worn.

Functional magnetic resonance imaging. This is the most popular data collection method in neuroscience (Grigaliūnaite \& Pilelienè, 2016). It is an indirect inflow of oxygen-filled blood to the active side of the brain. Magnetic and radio waves are used to create images in the brain (Cosic, 2016). Using functional magnetic resonance imaging, brain activity is assessed by recording changes in oxygen-saturated hemoglobin (oxy-Hb), oxygen-unsaturated hemoglobin (deoxy-HB), and total hemoglobin (HBT). Changes in hemoglobin or blood flow indicate activation of neurons (Hu \& Shealy, 2019). The functional magnetic resonance technique can be illustrated by an example. Suppose when a participant views a communication message, then light activates the lenses and pupils of both eyes, as well as about 125 million optic nerve receptors. Nerve impulses are transmitted to the intermediate brain. The brain focuses the pupils and coordinates eye movements in the field of the communication message. Other signals are transmitted by the pupils and lenses through nerve fibers and then reach the brain. The right part of the communication message is transmitted to the left and the left part to the right hemisphere. The left and right hemispheres of the brain are responsible for different activities. By taking the principles of brain functioning into account, organizations have the opportunity to create such communication messages, which are likely to enter the part of the brain that is most compatible with the nature of the product (Grigaliūnaite \& Pilelienė, 2016). The functional magnetic resonance technique is characterized by a wide spatial resolution, but the mobility and temporal resolution of the participants are limited (Hu et al., 2018; $\mathrm{Hu} \&$ Shealy, 2019). To date, this approach has hardly been applied to housing development decision-making.

Functional near-infrared spectroscopy, fNIRS. Performed by wearing a special head cover. In this cover, light is emitted from the sources to the scalp at specific wavelengths of 700 to $900 \mathrm{~nm}$. Hemoglobin and deoxygenated hemoglobin in the blood absorb more light than water and other tissues in the brain. An increase in hemoglobin in the brain is associated with an increase in cognitive activity. Unabsorbed light is reflected back to the detectors in the headgear and thus changes in cognitive activity can be measured. The different spectra of hemoglobin absorption make it possible to characterize the activated parts of the brain and cognitive activities through changes in hemoglobin concentration. An important advantage of this method is the ability to apply in a natural and comfortable environment. Functional near-infrared spectroscopy has better spatial resolution than electroencephalography and better temporary resolution than functional magnetic resonance imaging. Functional near-infrared spectroscopy is widespread in experiments with decision making in conditions of risk and uncertainty (Hu et al., 2018).

Eye tracking - it is the recording of a person's eye movements to determine where the person is looking at a particular point in time and in what order his/her eyes are moving from one place to another. Capturing the gaze of individuals creates preconditions for gaining insights about the distribution of attention, visual search strategies, cognitive processes. All this is organized and prioritized in the brain, and later reflected in behavior. Given a person's gaze correlates with attention, it can be argued, that the gaze capture technique creates the preconditions for researchers to assess a subject's attention distribution. In addition, with the help of gaze capture, it is possible to examine a person's awareness, perception, fatigue, cognitive processes. Based on the collected data, it is possible to make assumptions about the behavior of the observed person in the future. To this end, gaze capture technol-

Table 2. Researches employing electroencephalography

\begin{tabular}{|c|c|c|c|c|}
\hline Authors & Aim of the research & $\begin{array}{l}\text { Number of study } \\
\text { participants }\end{array}$ & Equipment used & Indicators measured \\
\hline $\begin{array}{l}\text { Jebelli et al. } \\
\text { (2017) }\end{array}$ & $\begin{array}{l}\text { Evaluate a signal processing } \\
\text { model to capture high quality } \\
\text { electroencephalographic signals }\end{array}$ & $\begin{array}{l}8 \text { healthy construction } \\
\text { professionals }\end{array}$ & Emotiv EPOC+ & $\begin{array}{l}\text { Rhythmic activity waves in } \\
\text { active and inactive working } \\
\text { conditions }\end{array}$ \\
\hline $\begin{array}{l}\text { Jebelli et al. } \\
\text { (2018) }\end{array}$ & $\begin{array}{l}\text { Assess the stress level of } \\
\text { construction sector workers }\end{array}$ & $\begin{array}{l}5 \text { healthy construction } \\
\text { professionals }\end{array}$ & $\begin{array}{l}\text { Wearing an } \\
\text { electroencephalography } \\
\text { device }\end{array}$ & Time, frequency, cortisol level \\
\hline
\end{tabular}


ogy evaluates the influence of an independent variable, the stimulus, on dependent variables (eye movement indicators) (Hasanzadeh et al., 2016, 2018).

This is a very popular neuroscience technique in market research. It is used not only in market research but also in disciplines such as software design, website design, psychology, human behavior research, game design (Mohammadpour et al., 2015; Habibnezhad et al., 2016). The use of eye capture techniques to identify risks to construction workers in housing development is quite common (Habibnezhad et al., 2016; Hasanzadeh et al., 2016, 2018). The popularity of this technique is probably due to the fact, that the subjects do not feel it, do not notice it, and their time is not wasted. On the other hand, this raises ethical dilemmas regarding informing participants about their participation in the market research. Often, the eye capture technique is combined with electroencephalography (Cosic, 2016). Attention should also be paid to the fact, that eye capture equipment is usually expensive, specific skills and knowledge are required to operate it. There is a lack of convenient, portable equipment with real-time data processing capabilities (Hasanzadeh et al., 2016). Over time, this equipment becomes more and more user-friendly, more cost-effective. As Mohammadpour et al. (2015) note, due to the different area of the eyeball, shapes, wearing glasses, which change the size of the eye, it is necessary to calibrate the eye capture equipment for each study participant. For the calibration procedure, the participant is asked to sit and relax in front of the eye capture chamber. The study participant is asked not to move. The participant then looks at the 9 calibration locations on the screen.

The eye capture technique uses mobile glasses or a stationary device with infrared cameras to determine where a person is directing their gaze (Tichy et al., 2012). According to Hasanzadeh et al. (2018), near-infrared technology and high-resolution cameras are required to track the direction of corneal reflection and gaze. According to the authors, this technology enables researchers to continuously observe the points of view on a $2 \mathrm{D}$ screen or in a $3 \mathrm{D}$ environment. Eye capture can be remote (during the experiment, the subject sits in front of the screen) and mobile (during the experiment, the subject is allowed to move freely).

Fixation and movement are measured using gaze tracking techniques. Fixation is marked when the user's gaze is relatively immobile at a specific location, and movement is defined by rapid movement of the gaze from fixations to other elements (Mohammadpour et al., 2015). Hasanzadeh et al. (2018) also recommend examining fixations (maintaining a relatively static eye position for $100-200 \mathrm{~ms}$ ) and movement (sudden eye movement between fixation points). And although at first glance Mohammadpour et al. (2015) and Hasanzadeh et al. (2018) offer similar indicators, however, as detailed examination shows, the content of one of these indicators, specifically movement, is different. According to Mohammadpour et al. (2015), motion is measured as the movement of the gaze from fixation to other elements, while Hasanzadeh et al. (2018) measure motion between fixation points. Habibnezhad et al. (2016) propose to evaluate the following indicators using the gaze capture technique:

- percentage of stopping time. The proportion of gaze stop time from the total stimulus demonstration time;

- duration of the first fixation. Duration of the study participant's first gaze fixation on the stimulus;

- percentage of fixation. Proportion of the number of fixations from all fixations during stimulus demonstration.

According to Tichy et al. (2012), the result of this method is a map with 'hotspots' showing where the gaze is most often directed. Mohammadpour et al. (2015) specify, that eye capture software (such as Mirametrix S2) collects eye position data depending on the interest and aggregated gaze fixations, displayed on the hotspot map. The 'hot spots' map is described by Hasanzadeh et al. (2018) as a $2 \mathrm{D}$ visualization in which all analyzed capture values are represented on color scales. Hotspot maps can be created for each study participant individually or for the entire study sample. This type of visualization provides useful generalized information. In addition to hotspot maps, eye movement paths are commonly used. The path of eye movement is a spatial representation of the movementcapture-movement of the gaze. The optimal path of movement is a straight line depicting the movement of the eye between the desired points. Because the path of movement shows the course of movement in the observed space, this result provides more important information than visualizations of fixation sites.

In eye-tracking studies to ensure 90 percent. reliability of the results, at least 20-30 participants would be needed (Grigaliūnaitė \& Pilelienè, 2016). In research using gaze capture techniques, the number of participants ranges from 8 to 27 (Table 3). In housing development studies using gaze capture techniques, various indicators have been measured showing gaze capture and movement.

Galvanic skin response. It is a biometric assessment, measuring a widely used measure called skin conductivity. Galvanic skin reactions are used to collect data on the amount of sweat released from the skin. These amounts are directly correlated with the strength of emotional arousal. When people face emotional events (such as stress, pleasure) in their daily lives, their sweat levels increase. As sweat levels increase, so do skin conduction reactions.

In some cases, different neuroscience techniques are combined together. Ergan et al. (2019) used the following techniques to evaluate human experience in architectural spaces. Which integrate virtual reality and body sensor networks: electroencephalogram to measure human brain electrical activity, galvanic skin reactions to measure skin electrical conductivity, facial or visual electromyography to determine facial expressions; eye capture to assess human eye movement in space and a photoplethysogram to measure changes in heart rate. 
Table 3. Researches employing eye tracking technique

\begin{tabular}{|c|c|c|c|c|}
\hline Authors & Aim of the research & $\begin{array}{l}\text { Number of study } \\
\text { participants }\end{array}$ & Equipment used & $\begin{array}{l}\text { Indicators of eye fixation } \\
\text { measured }\end{array}$ \\
\hline $\begin{array}{l}\text { Mohammadpour } \\
\text { et al. (2015) }\end{array}$ & $\begin{array}{l}\text { To determine end-user } \\
\text { satisfaction with the design } \\
\text { of a building project }\end{array}$ & 8 participants & $\begin{array}{l}\text { Mirametrix S2 eye } \\
\text { tracker }\end{array}$ & Fixation, movement \\
\hline $\begin{array}{l}\text { Habibnezhad } \\
\text { et al. (2016) }\end{array}$ & $\begin{array}{l}\text { To determine the } \\
\text { relationship between } \\
\text { construction sector workers' } \\
\text { risk perception and eye } \\
\text { movement risk identification }\end{array}$ & $\begin{array}{l}24 \text { construction workers } \\
\text { and } 6 \text { students with } \\
\text { experience in ancillary } \\
\text { work in the construction } \\
\text { sector }\end{array}$ & $\begin{array}{l}\text { SR Research EyeLink } \\
\text { II eye-fixation system, } \\
\text { worn on the head }\end{array}$ & $\begin{array}{l}\text { Percentage of stopping time, } \\
\text { duration of first fixation, } \\
\text { percentage of fixation }\end{array}$ \\
\hline $\begin{array}{l}\text { Hasanzadeh et al. } \\
(2016)\end{array}$ & $\begin{array}{l}\text { To establish real-time } \\
\text { cognition of the situation } \\
\text { of employees in the } \\
\text { construction sector }\end{array}$ & $\begin{array}{l}14 \text { bachelor and masters } \\
\text { students }\end{array}$ & $\begin{array}{l}\text { New generation } \\
\text { comfortable, light, } \\
\text { unobstrusive gaze- } \\
\text { catching glasses Tobii } \\
\text { Pro glasses } 2\end{array}$ & $\begin{array}{l}\text { Time to first fixation, number } \\
\text { of fixations, stopping time }\end{array}$ \\
\hline $\begin{array}{l}\text { Hasanzadeh et al. } \\
(2017)\end{array}$ & $\begin{array}{l}\text { To determine the influence } \\
\text { of safety knowledge on the } \\
\text { distribution of attention of } \\
\text { construction workers and } \\
\text { the detection of risks }\end{array}$ & $\begin{array}{l}27 \text { workers in the } \\
\text { construction sector }\end{array}$ & $\begin{array}{l}\text { SR Research EyeLink } \\
\text { II eye-fixation system, } \\
\text { worn on the head }\end{array}$ & $\begin{array}{l}\text { Percentage of stopping time, } \\
\text { duration of first fixation, } \\
\text { percentage of fixation }\end{array}$ \\
\hline $\begin{array}{l}\text { Hasanzadeh et al. } \\
(2018)\end{array}$ & $\begin{array}{l}\text { Establish a link between } \\
\text { construction workers' } \\
\text { visual attention or cognitive } \\
\text { collapse and other } \\
\text { hazardous conditions }\end{array}$ & $\begin{array}{l}14 \text { bachelor and master's } \\
\text { students }\end{array}$ & $\begin{array}{l}\text { New generation } \\
\text { comfortable, light, } \\
\text { unobtrusive gaze- } \\
\text { catching glasses Tobii } \\
\text { Pro glasses } 2\end{array}$ & $\begin{array}{l}\text { Fixation duration, stopping } \\
\text { time, number of fixations }\end{array}$ \\
\hline $\begin{array}{l}\text { Jeelani et al. } \\
(2018)\end{array}$ & $\begin{array}{l}\text { Determine the predictability } \\
\text { of hazard identification } \\
\text { through visual searches }\end{array}$ & $\begin{array}{l}23 \text { employees in the } \\
\text { construction sector }\end{array}$ & $\begin{array}{l}\text { EyeTech VT3 remote } \\
\text { eye tracker }\end{array}$ & $\begin{array}{l}\text { Number of fixations, duration } \\
\text { of fixations, average duration } \\
\text { of one fixation, spatial density } \\
\text { of fixation, stopping speed }\end{array}$ \\
\hline
\end{tabular}

After analyzing the techniques of electroencephalography, functional magnetic resonance, functional nearinfrared spectroscopy, gaze capture, the advantages and disadvantages of each of these techniques can be refined (Table 4).

An analysis of neuroscience techniques and advantages shows functional semi-infrared spectroscopy and galvanic skin reactions to have the weakest limitations, but this does not reveal the advantage of these techniques over other neuroscience techniques. It should be noted, in each case, the most appropriate technique should be selected depending on the purpose of the study, the context of the study, the available human, financial and time resources.

\subsection{Potential of application of neuroscience techniques for housing sector development}

The potential for the use of neuroscience techniques in housing development is quite wide. One of the applications of neuroscience - selection of the most appropriate incentives for the distribution of the product (in this case, housing as a good or a related service) for maximum consumer impact (Costa et al., 2015; Cosic, 2016; Grigaliūnaitè \& Pileliené, 2016). Traditional communication campaigns are characterized by large amounts of visual information, almost always supplemented by audio elements. Such traditional communication in today's changing environment often becomes incapable, insufficient and inappropriate for the communication message to reach the consumer. Therefore, it is only natural for some of the information to be simply ignored by the user. In order to increase brand recognition and strengthen consumer relations with the brand, Grigaliūnaite and Pileliené (2016) recommends ensuring a positive synergy of all five senses.

The application of neurosciences creates preconditions for the organization to determine the quantitative characteristics of the repetition of a communication message. Using neuroscience techniques, it is calculated how often it is appropriate to repeat a particular communication message in a specific communication channel (Grigaliūnaitè \& Pilelienè, 2016). Kaklauskas et al. $(2019,2020)$ have proved that neuromarketing provides huge benefits in choosing appropriate marketing communication. For that purpose authors have developed VINERS method that leads to the selection of a rational video advertisement for the target market segment. Cosic (2016) also confirms the potential of neuroscience in the area of marketing communication.

Another important area of application for the neurosciences is product development. An organization can learn what sensory stimuli embedded in product development would cause user satisfaction through neuroscience research (Mohammadpour et al., 2015; Grigaliūnaitè \& Pileliené, 2016). Tichy et al. (2012), Cosic (2016) recommend the application of neuroscience techniques in product design tests. 
Table 4. Advantages and disadvantages of neuroscience techniques

\begin{tabular}{|c|c|c|}
\hline Neuroscience techniques & Advantages & Disadvantages \\
\hline Electroencephalography & \begin{tabular}{|l} 
- Low application costs. \\
- Possibilities to apply the technique to small \\
samples. \\
- Possibility to apply the technique in a natural \\
and comfortable environment. \\
- Excellent temporary resolution. \\
- It is possible to accurately monitor neuronal \\
activity and brain wave structure by directly \\
reaching the central nervous system.
\end{tabular} & $\begin{array}{l}\text { - Poor spatial resolution. } \\
\text { - There is no possibility to distinguish cognitive acti- } \\
\text { vation from other parts of the brain involved in the } \\
\text { mental process. } \\
\text { - Obtaining high quality electroencephalographic sig- } \\
\text { nals is hampered by noise in the study environment. } \\
\text { - Complicated interpretation of collected data due } \\
\text { to interpretations of unknown signals in individual } \\
\text { parts of the brain. } \\
\text { - Additional data on biometric sensors are required } \\
\text { for data analysis. }\end{array}$ \\
\hline $\begin{array}{l}\text { Functional magnetic } \\
\text { resonance }\end{array}$ & $\begin{array}{l}\text { - Wide spatial resolution. } \\
\text { - If done correctly, there are no risks. } \\
\text { - Easy to apply. }\end{array}$ & $\begin{array}{l}\text { - Limited mobility of study participants. } \\
\text { - Limited provisional resolution. } \\
\text { - High financial costs. } \\
\text { - Ignore individual nerve cells (neurons), which are } \\
\text { essential for mental function. }\end{array}$ \\
\hline $\begin{array}{l}\text { Functional near-infrared } \\
\text { spectroscopy }\end{array}$ & $\begin{array}{l}\text { - Possibility to apply the technique in a natural } \\
\text { and comfortable environment. } \\
\text { - Better spatial resolution than electroencepha- } \\
\text { lography. } \\
\text { - Better temporary resolution than functional } \\
\text { magnetic resonance imaging. } \\
\text { - Non-invasive method. } \\
\text { - It is possible to determine the localization and } \\
\text { specialization of the nervous response. }\end{array}$ & $\begin{array}{l}\text { - Lack of a standardized signal processing method or } \\
\text { guidelines, leading to the need to choose the analysis } \\
\text { tools offered by the private business. } \\
\text { - The activity of neurons on the surface of the head is } \\
\text { measured without delving into the anatomical infor- } \\
\text { mation about the brain. } \\
\text { - Spatial resolution inferior to functional magnetic } \\
\text { resonance. }\end{array}$ \\
\hline Eye capture & $\begin{array}{l}\text { - Subjects may not feel or notice, that they are } \\
\text { participating in the study, there is no addi- } \\
\text { tional wasting of participants' time. } \\
\text { - Eye capture equipment is becoming more and } \\
\text { more convenient for users. }\end{array}$ & $\begin{array}{l}\text { - Ethical dilemmas regarding informing participants } \\
\text { about inclusion in the study. } \\
\text { - Calibration required for each study participant. } \\
\text { - Eye capture equipment is expensive. } \\
\text { - Specific skills and knowledge are required to operate } \\
\text { eye capture equipment. }\end{array}$ \\
\hline Galvanic skin reactions & $\begin{array}{l}\text { - The necessary equipment has become more } \\
\text { accessible and affordable. } \\
\text { - Unrestricted movement of the study partici- } \\
\text { pant. } \\
\text { - Quite simple application. } \\
\text { - Easy retesting. }\end{array}$ & $\begin{array}{l}\text { - False artifacts are possible if the study participant } \\
\text { makes sudden hand movements. } \\
\text { - False artifacts are possible in the event of large tem- } \\
\text { perature fluctuations. } \\
\text { - Differences in study response time in terms of stimu- } \\
\text { lus response may make it difficult to aggregate data. }\end{array}$ \\
\hline
\end{tabular}

The importance of involving the end user in the design process of housing and construction projects has recently been recognized. End users are those who will later live or work in the building. Even if these individuals do not have sufficient knowledge in housing management, they may have strong and reasoned opinions about the expected outcome. In order to involve end users in the design process, methods such as focus groups, working groups, and questionnaires are used. Despite the importance of these methods and the important contribution they make to understanding consumers and their needs, the application of these methods requires a considerable amount of time and effort, both in collecting and interpreting respondents' responses. For this reason, information and communication technologies are included in the cognitive processes of consumers and their needs. One of the methods proposed for this purpose is eye capture (Mohammadpour et al., 2015).

Vartanian et al. (2015) used brain science techniques to study brain activity in relation to housing. Using neu- ral imaging techniques, the authors found rooms with higher ceilings to be rated as more attractive compared to those with low ceilings. These assessments are related to activities in individual parts of the brain. Such insights can be useful in choosing the height of the ceiling in rooms, buildings. The neuroscience technique, and more specifically eye capture, was also used by Mohammadpour et al. (2015) to select housing design solutions. With the help of eye capture, home builders and developers can ensure the final result of the project will meet the needs of the home buyer. Mohammadpour et al. (2015) formulated the hypothesis of customer satisfaction with different design variations being related to their visual attention. In other words, more customer-friendly design alternatives are receiving more attention. The authors conducted an experiment using gaze tracking techniques to evaluate four facade design alternatives depicted in a 3D environment. Study participants were asked to rate their level of satisfaction with each alternative, and their interaction with each virtual model was measured using eye fixation. The 
results of the study conducted by the authors showed, that study participants do not necessarily look longer at the alternative which seems more attractive. Such research results are explained by the fact of more attention being paid not only to the alternative with which the participants are more satisfied, but also to the alternative with the lowest satisfaction. Moreover, focusing does not necessarily have to be equated with satisfaction. It was found, that more research participants were attracted by the design alternatives, which are dominated by warm colors, but more attention was also paid to the geometry and materials of the buildings.

Neuroscience techniques are also applied in selecting a product-specific pricing strategy. Different pricing solutions are appropriate for different categories of products. The neuromarketing paradigm helps to clarify the differences between such solutions. For example, the price of a daily consumer product is very different in nature from the price of a branded product. This is confirmed by the change in the location of brain activity, assessing prices together with associations (Pilelienè, 2012).

As the analysis of neuroscience applications shows, the applications of neuroscience techniques have a broad spectrum. And while the spectrum is wide, none of the areas are inseparable from at least one element of the marketing complex. Therefore, all the discussed areas of application of neurosciences are divided according to the elements of the marketing complex (Table 5).

As the analysis has shown, neuroscience techniques can involve the fulfillment of each element of the marketing complex. This performance may vary depending on the organizational context and, more specifically, the sector in which the organization operates. One of the sectors, which is characterized by the specific expression of neuroscience applications, is the field of housing development. In the beginning of the 21st century, Schaufelberger (2000) highlighted the transformation inherent in building marketing, involving increasingly more marketers, who were savvy and professional. Human capital, able to select the most appropriate neuroscience technicians in a particular case and apply them effectively, is becoming a very valuable factor in creating a competitive advantage in housing development.
It is clear, neuroscience has great potential for application in housing development. In realizing this potential, it is important to pay attention to potential challenges as well. For example, Ulman et al. (2015), Mileti et al. (2016), Stanton et al. (2017) draw attention to ethical issues in the use of neuroscience. According to the authors, ethical dilemmas are receiving more and more attention in the light of the expanding neuroscience research market. As the authors note, year 2015 data show there were more than 300 neuromarketing research companies worldwide (Ulman et al., 2015). It is important for neuroscience technologies to be publicized and used in human behavior research without violating ethical principles and legal requirements in the areas of human rights and dignity (Ulman et al., 2015; Cosic, 2016).

Summarizing neuroscience research, neuroscience techniques are divided into three groups of different content: 1) instantaneous techniques for measuring changes in electronic neuronal activity; 2) techniques for measuring changes in metabolic neuronal activity; 3) techniques for measuring changes in the psychological response to a marketing stimulus. After the analysis of separate groups belonging to these neuroscience techniques, it was found, that electroencephalography, functional magnetic resonance, eye capture, all have great potential for application in the field of housing development. These and other techniques are used to make marketing decisions related to individual elements of the marketing complex.

\section{Conclusions}

1. In the field of housing development, in order to improve the sale of housing by better responding to the needs of potential buyers, the transferable and adaptable solutions from other areas are gaining more and more weight. Neuroscience has been used for some time for the development of housing as an object, demonstrating the strengthening of interdisciplinarity, among other measures to improve sales. After systematizing the knowledge about the most commonly presented interpretations of the concepts of neuromarketing, the scientific knowledge of this field was supplemented and the defini-

Table 5. Classification of neuroscience application fields according to elements of mareting complex

\begin{tabular}{|l|l|l|}
\hline $\begin{array}{c}\text { Elements of the } \\
\text { marketing complex }\end{array}$ & \multicolumn{1}{|c|}{ Neuromarketing activities } & \multicolumn{1}{c|}{ Representatives } \\
\hline Product & Product development & $\begin{array}{l}\text { Schneider and Woolgar (2012), Mohammadpour et al. } \\
\text { (2015), Vartanian et al. (2015), Cosic (2016), Grigaliūnaite } \\
\text { and Pilelienè (2016), Ergan et al. (2019) }\end{array}$ \\
\hline Price & Choosing a pricing strategy & Pilelienè (2012) \\
\hline Distribution & $\begin{array}{l}\text { Selection of the most appropriate product } \\
\text { distribution incentives }\end{array}$ & Grigaliūnaitė and Pilelienè (2016) \\
\hline Sponsorhip & $\begin{array}{l}\text { Determining repetition characteristics of a } \\
\text { quantitative marketing communication message }\end{array}$ & $\begin{array}{l}\text { Schneider and Woolgar (2012), Costa et al. (2015), } \\
\text { Cosic (2016), Grigaliūnaite and Pileliene் (2016) }\end{array}$ \\
\hline
\end{tabular}


tion of neuromarketing was clarified. It was found, that the concept of neuromarketing has expanded from the application of neuroscience methods to an interdisciplinary field of science. Neuromarketing and its techniques create preconditions for paying attention to the emotions of potential home buyers, their emotional states, which can be considered as a basis for setting consumer needs and priorities.

2. After analyzing the latest research in the field of neuroscience, the main groups of neuroscience techniques are classified (momentary techniques for measuring changes in electronic neuronal activity, techniques for measuring changes in metabolic neuronal activity, techniques for measuring changes in psychological response to stimuli). A detailed review of the techniques of electroencephalography, functional magnetic resonance, functional near-infrared spectroscopy, eye capture and galvanic skin reaction, identification of advantages and limitations has shown, that these techniques are not ideal for every case. The choice of specific techniques in each case is determined by the purpose of the research, the context, and the available financial, human and time resources.

3. It has been established, that in the field of housing development, neuroscience techniques can be used to make marketing decisions related to individual elements of the marketing complex (product, price, distribution, sponsorship), working with target audiences of different ages, life experiences, characteristics who want to live where they feel themselves best. In the future it is essential to analyse specifics of empirical researches of neuromarketing in the field of housing development.

4. In order to confirm the suitability of neuroscience techniques in the field of housing development, in the future, empirical research is needed to enable the selection and substantiation of the most appropriate housing marketing solutions. This could simplify the process of advertising homes for sale, improve the quality of videos and make them more interesting and effective.

\section{References}

Adhami, M. (2013). Using neuromarketing to discover how we really feel about apps. International Journal of Mobile Marketing, 8(1), 95-103.

Agarwal, S., \& Dutta, T. (2015). Neuromarketing and consumer neuroscience: current understanding and the way forward. Decision, 42(4), 457-462.

https://doi.org/10.1007/s40622-015-0113-1

Awolusi, I., Nnaji, C., Marks, E., \& Hallowell, M. (2019). Enhancing construction safety monitoring through the application of internet of things and wearable sensing devices: a review. In Computing in Civil Engineering 2019 (pp. 530-538). American Society of Civil Engineers, Atlanta. https://doi.org/10.1061/9780784482438.067
Brenninkmeijer, J., Schneider, T., \& Woolgar, S. (2020). Witness and silence in neuromarketing: managing the gap between science and its application. Science, Technology, \& Human Values, 45(1), 62-86. https://doi.org/10.1177/0162243919829222

Cariaga, I., \& El-Diraby, T. E. (2013). Assessing the market potential for housing construction products in Mexico. Assessing the Market Potential for Housing Construction Products in Mexico, 139(6), 717-725.

https://doi.org/10.1061/(ASCE)CO.1943-7862.0000637

Cosic, D. (2016). Neuromarketing in market research. Interdisciplinary Description of Complex Systems, 14(2), 139-147. https://doi.org/10.7906/indecs.14.2.3

Costa, J. V., Freitas, C. L., \& Paiva, T. (2015). Brain imaging during advertsing: a neuromarketing dtusy of sound and pictures. The Marketing Review, 15(4), 405-422. https://doi.org/10.1362/146934715X1450349053594

Dale, E., Nobe, M. E. C., Clevenger, C., \& Cross, J. (2012). Community-based social marketing: An application to facilities management. International Conference on Sustainable Design, Engineering, and Construction 2012 (pp. 552-560). American Society of Civil Engineers, Fort Worth. https://doi.org/10.1061/9780784412688.066

Ergan, S., Radwan, A., Zou, Z., Tseng, H., \& Han, X. (2019). Quantifying human experience in architectural spaces with integrated virtual reality and body sensor networks. Journal of Computing in Civil Engineering, 33(2), 1-14. https://doi.org/10.1061/(ASCE)CP.1943-5487.0000812

Eser, Z., Isin, F. B., \& Tolon, M. (2011). Perceptions of marketing academics, neurologists, and marketing professionals about neuromarketing. Journal of Marketing Management, 27(7-8), 854-868. https://doi.org/10.1080/02672571003719070

Grigaliūnaitè, V., \& Pilelienè, L. (2016). Reklamos pardavimo vietoje padetis: neuromarketingo aspektas. Management Theory and Studies for Rural Business and Infrastructure Development, 38(4), 359-367. https://doi.org/10.15544/mts.2016.28

Habibnezhad, M., Fardhosseini, S., Vahed, A. M., Esmaeili, B., \& Dodd, M. D. (2016). The relationship between construction workers' risk perception and eye movement in hazard identification. In Construction Research Congress (pp. 2984-2994). American Society of Civil Engineers, New Orleans. https://doi.org/10.1061/9780784479827.297

Harris, J. M., Ciorciari, J., \& Gountas, J. (2018). Consumer neuroscience for marketing researchers. Journal of Consumer Behaviour, 17, 239-252. https://doi.org/10.1002/cb.1710

Hasanzadeh, S., Esmaeili, B., \& Dodd, M. D. (2016). Measuring construction workers' real-time situation awareness using mobile eye-tracking. In Construction Research Congress 2016 (pp. 2894-2904). American Society of Civil Engineers, San Juan. https://doi.org/10.1061/9780784479827.288

Hasanzadeh, S., Esmaeili, B., \& Dodd, M. D. (2017). Measuring the impacts of safety knowledge on construction workers' attentional allocation and hazard detection using remote eyetracking technology. Journal of Management in Engineering, 33(5), 1-17.

https://doi.org/10.1061/(ASCE)ME.1943-5479.0000526

Hasanzadeh, S., Esmaeili, B., \& Dodd, M. D. (2018). Examining the relationship between construction workers' visual attention and situation awareness under fall and tripping hazard conditions: Using mobile eye tracking. Journal of Construction Engineering and Management, 144(7), 1-18. https://doi.org/10.1061/(ASCE)CO.1943-7862.0001516 
Hu, M., \& Shealy, T. (2019). Application of functional near-infrared spectroscopy to measure engineering decision-making and design cognition: literature review and synthesis of methods. Journal of Computing in Civil Engineering, 33(6), 1-18. https://doi.org/10.1061/(ASCE)CP.1943-5487.0000848

Hu, M., Shealy, T., Hallowell, M., \& Hardison, D. (2018). Advancing construction hazard recognition through neuroscience: measuring cognitive response to hazards using functional near infrared spectroscopy. In Construction Research Congress 2018: Construction Information Technology. American Society of Civil Engineers, New Orleans.

https://doi.org/10.1061/9780784481288.014

Hubert, M., \& Kenning, P. (2008). A current overview of consumer neuroscience. Journal of Consumer Behaviour, 7, 272 292. https://doi.org/10.1002/cb.251

Jebelli, H., Hwang, S., \& Lee, S. (2017). An EEG signal processing framework to obtain high quality brain waves from an off-the-shelf wearable EEG device. Journal of Computing in Civil Engineering, 32(1), 1-38.

https://doi.org/10.1061/(ASCE)CP.1943-5487.0000719

Jebelli, H., Khalili, M. M., Hwang, S., \& Lee, S. (2018). A supervised learning-based construction workers' stress recognition using a wearable Electroencephalography (EEG) device. Construction Research Congress (pp. 40-50). American Society of Civil Engineers, New Orleans.

https://doi.org/10.1061/9780784481288.005

Jeelani, I., Albert, A., Han, K., \& Azevedo, R. (2018). Are visual search patterns predictive of hazard recognition performance? Empirical investigation using eye-tracking technology. Journal of Construction Engineering and Management, 145(1), 1-39. https://doi.org/10.1061/(ASCE)CO.1943-7862.0001589

Kaklauskas, A., Dzitac, D., Sliogeriene, J., Lepkova, N., \& Vetloviene, I. (2019). VINERS method for the multiple criteria analysis and neuromarketing of best places to live. International Journal of Computers Communications \& Control, 14(5), 629-646.

Kaklauskas, A., Zavadskas, E. K., Schuller, B., Lepkova, N., Dzemyda, G., Sliogeriene, J., \& Kurasova, O. (2020). Customized ViNeRS method for video neuro-advertising of green housing. International Journal of Environmental Research and Public Health, 17, 1-28. https://doi.org/10.3390/ijerph17072244

Lee, N., Broderick, A. J., \& Chamberlain, L. (2007). What is 'neuromarketing'? A discussion and agenda for future research. International Journal of Psychophysiology, 63, 199-204. https://doi.org/10.1016/j.ijpsycho.2006.03.007

Levallois, C., Smidts, A., \& Wouters, P. (2019). The emergence of neuromarketing investigated through online public communications (2002-2008). Business History. https://doi.org/10.1080/00076791.2019.1579194

Liang, Y., \& Gao, Z. (2018). Marketing strategy analysis of commercial real estate Project Park I of Kaili city. In International Conference on Construction and Real Estate Management 2018. American Society of Civil Engineers, Charleston. https://doi.org/10.1061/9780784481745.010

McDowell, W. S., \& Dick, S. J. (2013). The marketing of neuromarketing: brand differentiation strategies employed by prominent neuro-marketing firms to attract media clients. Journal of Media Business Studies, 10(1), 25-40. https://doi.org/10.1080/16522354.2013.11073558

Mileti, A., Guido, G., \& Prete, M. I. (2016). Nanomarketing: a new frontier for neuromarketing. Psychology \& Marketing, 33(8), 664-674. https://doi.org/10.1002/mar.20907

Mohammadpour, A., Karan, E., Asadi, S., \& Rothrock, L. (2015). Measuring end-user satisfaction in the design of building pro- jects using eye-tracking technology. In Computing in Civil Engineering 2015 (pp. 564-571). American Society of Civil Engineers, Austin. https://doi.org/10.1061/9780784479247.070

Oliveira, J. H. C., \& Giraldi, J. M. E. (2017). What is neuromarketing? A proposal for a broader and more accurate definition. Global Business and Management Research: an International Journal, 9(2), 19-29.

Pileliené, L. (2011). Neuromarketingo principai ir nauda organizacijoms: teorinis aspektas. Management Theory and Studies for Rural Business and Infrastructure Development, 29(5), 147-151.

Pilelienè, L. (2012). Neuromarketingo principų taikymas kainodaroje: teorinis aspektas. Management Theory and Studies for Rural Business and Infrastructure Development, 30(1), 97-102.

Ruževičiūtè, R. (2012). Neuromarketing: concept and insights for application in marketing communications. International Business: Innovations, Psychology, Economics, 2(5), 35-43.

Schaufelberger, J. E. (2000). Marketing construction services. In Construction Congress VI: Building Together for a Better Tomorrow in an Increasingly Complex World. American Society of Civil Engineers, Orlando.

https://doi.org/10.1061/40475(278)51

Schneider, T., \& Woolgar, S. (2012). Technologies of ironic revelation: enacting consumers in neuromarkets. Consumption Markets \& Culture, 15(2), 169-189.

https://doi.org/10.1080/10253866.2012.654959

Shealy, T., \& Hu, M. (2018). Opportunities to advance engineering cognition and project level decision making by adopting emergent methods from neuroscience. In Construction Research Congress 2018: Construction Information Technology. American Society of Civil Engineers, New Orleans. https://doi.org/10.1061/9780784481264.013

Stanton, S. J., Sinnott-Armstrong, W., \& Huettel, S. A. (2017). Neuromarketing: ethical implications of its use and potential misuse. Journal of Business Ethics, 144, 799-811.

https://doi.org/10.1007/s10551-016-3059-0

Tichy, J., Rosenlacher, P., \& Maršalkova, L. (2012). Neuromarketing approach to efficient food styling. Journal of Interdisciplinary Research, 64(78), 180-183.

Ulman, Y. I., Cakar, T., \& Yildiz, G. (2015). Ethical issues in neuromarketing: 'I consume, therefore I am!'. Science \& Engineering Ethics, 21, 1271-1284.

https://doi.org/10.1007/s11948-014-9581-5

Vartanian, O., Navarrete, G., Chatterjee, A., Fich, B., Mora, L. G., Leder, H., Nadal, M. M. N., Rostrup, N., \& Skov, H. (2015). Architectural design and the brain: effects of ceiling heigh and perceived enclosure on beauty judgments and approachavoidance decisions. Journaal of Environmental Psychology, 41, 10-18. https://doi.org/10.1016/j.jenvp.2014.11.006

Wang, H., \& Liu, J. (2013). Adverse selection problem in the market of real estate. In International Conference on Construction and Real Estate Management 2013. American Society of Civil Engineers, Karlsruhe. https://doi.org/10.1061/9780784413135.102

Zeng, L., Qiu, Y., Peng, Y., \& Zhou, S. (2015). Research on the marketing planning and design of the Yongzhou Wuxi estate Project. In ICCREM 2015: Environment and the Sustainable Building. American Society of Civil Engineers, Lulea. https://doi.org/10.1061/9780784479377.094

Zhou, X., Zhang, S., \& Yang, S. (2015). Research on customer satisfaction in the market of pension real estate. In ICCREM 2015: Environment and the Sustainable Building. American Society of Civil Engineers, Lulea. https://doi.org/10.1061/9780784479377.103 